\title{
Equity pattern, corporate governance and performance a study of India's corporate sector
}

\author{
Patibandla, Murali
}

Document Version

Final published version

Publication date:

2001

\section{License \\ CC BY-NC-ND}

Citation for published version (APA):

Patibandla, M. (2001). Equity pattern, corporate governance and performance: a study of India's corporate sector.

Link to publication in CBS Research Portal

\section{General rights}

Copyright and moral rights for the publications made accessible in the public portal are retained by the authors and/or other copyright owners and it is a condition of accessing publications that users recognise and abide by the legal requirements associated with these rights.

Take down policy

If you believe that this document breaches copyright please contact us (research.lib@cbs.dk) providing details, and we will remove access to the work immediately and investigate your claim. 
Murali Patibandla

\section{Equity Pattern, Corporate Governance} and Performance: A Study of India's Corporate Sector

WP $9-2001$ 


\title{
Equity Pattern, Corporate Governance and Performance: A Study of India's Corporate Sector
}

\section{Murali Patibandla \\ Dept of International Economics and Management \\ Copenhagen Business School}

\begin{abstract}
:
In the literature on corporate governance, large outside investors are generally observed to reduce agency costs of corporate governance by monitoring and disciplining managers. This paper separates large investors into foreign investors and government owned local financial institutions and argues that the later have higher degree of moral hazard. The empirical results of the paper, based on firm level panel data for 11 Indian industries, show that foreign investors contribute positively to corporate performance in terms of profitability while the government financial institutions contribute negatively. Reducing the role of government financial institutions and opening up of the equity markets to foreign investors under effective regulatory mechanisms should improve corporate governance in terms of increasing transparency in developing economies. This, in turn, contributes positively to economic growth.
\end{abstract}

Keywords: foreign equity, government financial institutions, corporate governance JEL classification: D2, G3, L2

First Draft: October 2001 


\section{Introduction}

Public savings are channeled into investment through multi-layer agency relations in an economy as separation of ownership and control of capital operates pervasively right from banks, pension funds, insurance companies, stock market and even paying taxes to

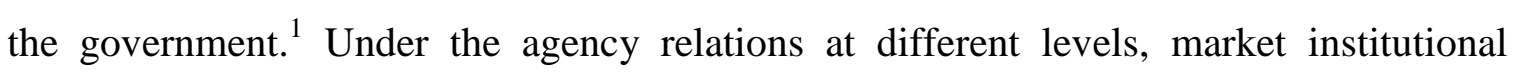
conditions that reduce informational imperfections and facilitate effective monitoring and incentives of owners and agents of capital determine efficiency of investment. In the case of corporate governance, efficiency of corporate investment is a function of institutional factors such as the quality of auditing and disclosure which reduce informational imperfection and the degree to which the legal and regulatory system that enforces contracts (Stein, 2001). Information and monitoring of agents actions is also governed by how the investors are organized into a large number of small investors and a few large players. This, in turn, determines effectiveness of the legal system in protecting investors interests (La Porta et al, 2000). The institutions that govern corporate governance are different in different countries with varying degrees of protection of investors (Shleifer and Vishny, 1997; Moerland, 1995). Countries, which have developed institutional mechanisms to reduce the agency costs of investment, tend to utilize accumulated capital more efficiently and realize higher economic growth compared to those with highly inefficient institutional mechanisms.

\footnotetext{
${ }^{1}$ In several countries governments protect banking failures, which induce moral hazard on the part of the banks in terms of reckless lending.
} 
One of the explanation for low economic growth in several developing economies is observed to be under-developed financial markets and market institutions, which beset high degree of agency costs at different levels (Beck et al, 2000). An example could be Indian Economy in 1970s and 1980s, India achieved a high annual savings rate of 20 percent during the period but a very low economic growth rate of 3 percent (Bhagwati, 1993). One of the reasons could be misallocation and inefficient use of public savings by the private and public sector financial institutions and corporations run by the public and private agents with high degree of moral hazard. This problem gets magnified if the product markets are non-competitive which allows managers to show high profits despite overall inefficiency (Patibandla, 1998, 1997).

In the recent years there has been increasing globalization of financial markets. The opening up of capital markets in several countries has increased not only the flow of foreign investment into them but also the economic and political pressure to create financial instruments acceptable to foreign investors. This has caused several forms of functional convergence in institutional conditions across countries (La Porta et al, 2000; Henry (2000); Stultz, 1999). In other words, the market reforms in several developing and East European Economies have important implications on economic growth through their implications on corporate governance.

Since the initiation of market reforms in 1991, Indian economy has grown at an annual growth rate of 6 percent. One of the important elements of the reforms is opening up to multinational investment and foreign financial institutions. This has implications on the evolution of institutions of corporate governance. This paper examines the issue of 
effect of the increasing role of foreign equity participation on corporate performance in the case of India.

There is a body of literature that shows that organization of investors in terms of large number small equity investors and a few large institutional investors have implications on managerial efficiency. A large number of small investors' ability to monitor managers is low owing to high costs of information and free rider outcomes. This problem gets magnified if there is poor legal mechanism in protecting small investors. On the other hand, large investors and financial institutions can afford to invest in information and effectively monitor managers and reduce conflict of interests of owners and managers (Shleifer and Vishny 1986). Following from this literature, this paper develops a simple theory and tests the hypotheses empirically. The objective of the paper is rather limited that it examines the role of large outside investors on corporate performance. It especially looks at the issue of whether increasing foreign equity participation improves corporate performance in terms of profitability in India's corporate sector.

\section{l.i. The Background}

From 1950 to 1991 India followed an inward oriented import substitution policy regime with pervasive government intervention through industrial licensing policies. The government of India played an active role in channeling savings into investment through nationalized banks, and public sector financial institutions (Bhagwati, 1993). Under this policy regime, private firms who were able to capture the industrial licenses and the public financial institutions built highly diversified family run industrial empires with a 
high degree of market power. The corporate governance institutional mechanism is explained briefly in the following.

In the 1950s and 1960s, the government of India set up three all-India development finance corporations (DFIs): the Industrial Finance Corporation of India (IFCI), the Industrial Development Bank of India (IDBI) and the Industrial Credit and Investment Corporation of India (ICICI). The objective of these public sector financial institutions is to foster industrialization by providing long term loans at low, often subsidized, real interest rates for setting up plant and machinery (Goswami, 2001). These institutions were judged by the amount of loans sanctioned but not by their asset quality under soft budget constraints, which led to strong moral hazard behavior on the part of the agents of these institutions. The overall derigiste policy regime led to strong collusion between the politicians, bureaucrats and large industrialists. 3 B By capturing these financial institutions, the promoters were able to set up industrial units and diversify into unrelated activities with little stake of their own investment but with high control rights. A small part of the equity would be issued to the public in order to retain a high degree of control rights and reduce the threat of takeovers. This led to domination of Indian industries with highly diversified family run businesses with poor corporate governance practices (Piramal, 1996; Business Today, 1999).

\footnotetext{
${ }^{2}$ Later on the government also set up the public sector mutual fund, the Unit Trust of India which used small investors savings for investing in the equity markets.

${ }^{3}$ Goswami (2001) observes that nexus between business groups and politicians ensured that debts would invariably reschedule in the event of defualt. Inefficient implementation of bankruptcy laws created wide spread corporate misgovernance, the least of which was major diversion of DFI funds for other ventures.
} 
The Indian government initiated market reforms in 1991. The reforms have been in terms of dismantling the industrial licensing, opening up Indian economy to multinational investment and foreign financial institutions. The reforms led to entry of quite a large number of multinationals with joint collaborations with local partners (Patibandla, 2001) and also to foreign financial institutions (FIIs). In 1992, the Government of India announced the opening up of the country's stock markets to direct participation by FIIs, such as Pension Funds, Mutual Funds, Investment Trusts, and Asset Management Companies. They are permitted to invest in all the securities traded on the primary and secondary markets. These would include shares, debentures, warrants and schemes floated by domestic mutual funds. This has led to increasing role of FIIs in the India's equity markets (see Table 1).

Apart from this, the reforms also led to entry of a large number of professionally run local firms into several industries while the old style family run businesses still continue to operate. The DFIs still continue to play an important role in the debt financing of the Indian corporations.

As shown in Table 1, FIIs investment increased from \$ 827 million in 1993 to \$ 10.2 billion by 1999 . They account for about 15 per cent the average daily volume of trade. It is observed that FIIs have steadily raised their demands for better corporate governance, more transparency and greater disclosure (Goswami, 2001; Khanna and Palepu, 1999). This paper, as stated earlier, examines this issue of FIIs effect on the corporate performance in India. 
The paper is organized as follows. In Section 2, a simple theory is formulated to bring out hypotheses for empirical testing. The empirical analysis is presented in Section 3. The concluding remarks are made in Section 4.

\section{Theory and Hypotheses}

Corporate performance is taken in terms of profitability. By taking the simple case of a two firm Cournot Oligopoly, the profit function is:

$\Pi_{i}=P\left(q_{i}+q_{j}\right) q_{i}-c\left(q_{i}\right)$

From the revenue function, firm $i$ will have higher profits than $j$ if it is able to internalize $j$ 's reaction function. On the cost function side, if $i$ is able to invest in assets such as $\mathrm{R} \& \mathrm{D}$ better than $j$ it will have superior technology. Consequently, firm $i$ will realize higher market share and profits. In the main stream oligopoly theory there is no reason, except for some exogenous factors, why firm $i$ is in a better position to invest in productive $\mathrm{R} \& \mathrm{D}$ than $j$. Organizational concepts such as informational imperfections, bounded rationality and managerial incentives provide some explanations for differences in the performance of firms (Jensen and Meckling, 1976; Williamson, 1985). In this paper, we concentrate on incentives of managers under agency relations. Bolton and Scharfstein (1998) show that an integrated firm as being comprised of two tiers of agency relationships: at the top between corporate headquarters and investors, and below that, between corporate head quarters and division managers. This paper focuses on the first one.

Firms $i$ and $j$ are represented by agents (managers) who raise capital externally from two large and a large number of small investors. We take two large investors, $x$ and 
$y$, who themselves have agency relations of managing other people's money for investing in firms. We take $x$ to be a large foreign institutional investor and $y$ to be a public sector financial institution. It is well established in the literature that large investors are able to protect their investment better than large number of small investors because of their incentive and ability to invest in information and monitor performance of the agents (Shleifer and Vishny, 1986).

The agency costs of large investors determine the extent of monitoring and discipline of the managers of firms. Large investors, as the institutional investors, are also agents with their own source of agency conflicts (Black 1992; Woidtke, 2001) In other words, the degree of moral hazard of the managers of the large financiers towards their own stake holders influence their effectiveness in monitoring managers of the firms. Furthermore, under the multiple agency relations, there is scope for collusion between the agents of large investors and firms for diverting capital for personal gains. This is explained in the following.

The government owned large investor $y$ is undertakes debt financing of firms. While foreign large investors $x$ undertakes equity financing. The agency costs (moral hazard) of $y$ are higher than that for $x$, for the following reasons. The agent representing $y$ is a government employee. The agent has employment security with the contract with the government. The government uses the taxpayers' money to finance $y$. Tax payers are diffused and their monitoring of government's performance is inefficient (Woidtke, 2001). As a result, government agents have low incentives in monitoring and disciplining the agent of the public financial institution. 
The large investor $x$ is a privately run foreign financial institution. The employment of agent representing $x$ is subject to performance in terms of showing returns on investment: the investors could remove him or her if there are consistent losses (or withdraw their funds). Consequently, the agent of $y$ is subject to higher degree of moral hazard than the agent of $x$. This is similar to Woidke's (2001) characterization of the public and private pension funds in which in the public funds are subject to higher degree of moral hazard because when it does not perform well enough the shortfall comes from tax payers. As taxpayers are much more diffused than corporate shareholders, they are less likely to monitor the performance of public pension fund administration.

The agency costs of $y$ can arise in several ways. Employment security and poor monitoring by the government can induce shirking by the agent of $y$ in monitoring the performance of the agents to whom the loan is sanctioned. Secondly there could be collusion between the agent of $y$ and the agents of firms to divert the funds for personal gains. Agents of both firm $i$ and $j$ have incentive to collude with the agent of $y$ for getting access to easy money. We take that for some exogenous reasons, the agent of firm $i$ is able to move in first and collude with the agent of $y$. This leads to inefficient use of capital in several ways which reduces the profits of firm $i$. The result of the collusion could be that a part of the loan is paid off as a commission (bribes) to the agent of $y$. The agent of firm $i$ can divert the capital through transfer pricing by setting up different units by himself or his family members or cronies: selling the output to these units below its opportunity costs. Furthermore, he can use the funds for empire building through horizontal (unrelated businesses) and vertical diversification. The agent of firm $i$ can pay himself high compensation for low effort (Shleifer and Vishney, 1997). Furthermore, 
capturing of the public financial institutions helps the agent of firm $i$ to reduce the threat of takeovers. This is because by resorting to the debt finance from the public financial institutions and issuing a very limited public equity, the agent retains high control rights and reduces the threat of take-over by large shareholders. The low take-over threat results in shirking and low effort by the agent of firm $i$. This is contrary to Shleifer and Vishny's (1986) argument that when there is poor performance of managers, large shareholders facilitate takeovers by outsiders by internalizing an increase in value of their own shares resulting from takeovers.

From the above observation, if firm $j$ depends mostly on the large investor $x$, its profits should be higher those of firm $i$, as x's agent has higher incentive in monitoring and disciplining the manger of firm $j$. This positive effect on profits need not be linear as there are agency costs in the case of large private investors (Shleifer and Vishny, 1986; Thomsen and Pedersen, 2000). If a large investor has high control rights over the firm, managers and employees may not have incentives to acquire firm specific capital and thereby reducing potential efficiency gains. If there are multiple investors in a single firm, it leads to incentive for redistribution of funds in their favor by the majority stakeholders through collusion (Jensen and Meckling, 1976). If control rights are concentrated in the hands of a small number of investors they could distort information and redistribute cash flows in their favor at the cost of dispersed small investors and employees. This can reduce efficiency by reducing employee incentives to acquire firm specific human capital (Schmidt 1990, Cremer, 1995). If costs of risk taking can be 
passed to the other investor, the large investors could force the managers of the firm to take undue risks.

\section{The Hypotheses:}

From the discussion above, the following hypotheses are formulated for empirical testing.

1. Higher is the share of a large foreign financial institution in the total investment of a firm; higher should be its profits. However the relationship is not monotonic if the agency costs associated with redistribution of cash flows and low powered incentive of the managers of the firm increase as the share of large investors increase.

2. Higher the share of public financial institutions in the total investment of a firm, lower should be the profits because of the agency costs associated with the managers of public financial institutions. Secondly, higher this share higher is diversification of firms as managers have incentive to pursue inefficient empire building.

3. Higher is the share of the small investors lower are the profits because lower ability of dispersed small investors in monitoring the agents of firms.

\section{Empirical Analysis}

The empirical analysis is based on firm level panel data for 11 Indian industries covering the time period of 1989 to 1999 . These industries are chosen for the noticeable level of foreign equity presence in the industries. Table 2 presents the summary statistics of the data. The data is collected from the publications of the Center for Monitoring Indian

\footnotetext{
${ }^{4}$ If both large investors $x$ and $y$ invest in firm $i$, all the three agents have an incentive to collude and pass on the costs of risk to tax payers.
} 
Economy, which compiles comprehensive data for publicly listed companies in India. These publications provide the equity holding pattern for the companies in terms of percentage share of foreign equity, public financial institutions and the public (small investors). For each firm in the sample, the figures of the percentages of the different equity holding remain constant for the 11-year time period. The firm level data for all the industries are pooled into one sample. Industry dummies are used to capture the fixed effects of the panel data (Cheng, 1986). The industry dummies also reduce the bias owing to omitted variables in the econometric estimations.

\section{The Variables}

$P R$ net profits/sales

$F E$ percentage share of foreign equity

$P E$ percentage share of investment of public financial institutions. This includes

investment by the government institutions, IDBI, ICICI and IFCI.

$P B E$ percentage share of the small investors equity

$T E$ technical efficiency of firms (see Appendix for the measurement issues)

It is measured for each industry separately.

$H I$ Herfindal Index of market concentration: Sum of squared market shares of firms

It is measured for each industry separately

$A D S$ advertising expenditure/sales

$V E$ vertical integration (value-added/output) 


\section{The Results}

Percentage share of different investors $(F E, P E$ and $P B E)$ are correlated because these shares, along with the share of directors and corporate bodies (which are not considered in this paper) add up to 'one': if one of them increases one of the other (or all the others) has to decrease. In order to avoid the multi-colinearity, these variables are introduced separately in estimating their relation with profitability of firms.

There can be simultaneity in the relation between profitability of firms and foreign equity. As discussed in the previous section, higher the share of foreign equity higher are the profits because of low agency costs of foreign institutional investors. On the other hand, this relation could be other way round because when foreign financial institutions enter the Indian market in making their investment decisions they would choose relatively efficient and profitable companies and avoid inefficient firms by investing in information. For this reason, simultaneous system of equations is estimated by using an instrumental variable. Technical (production) efficiency variable is used as the instrumental variable for profitability. It is theoretically consistent that higher the technical efficiency (lower are costs of production) higher are profits. The correlation coefficient for these two variables $(T E$ and $P R$ ) is 0.12 significant at 0.01 level (twotailed test).

In explaining the profitability of firms, additional explanatory variables of market concentration of industries $(H I)$ and firm level advertising intensity $(A D S)$ are introduced to control for market structure effects on firm level profits. Industries with high degree of concentration generally exhibit higher profits owing to entry barriers arising out of 
economies of scale (fixed costs) in Research and Development and Advertising (Sutton, 1992). These variables should explain profits positively.

1. $P R=-1.7+0.030(F E)-0.00033(F E)^{2}+5.3 \mathrm{HI}-3.1 A D S-0.53 D 1-1.18 D 2$

$$
\begin{aligned}
& \begin{array}{llllll}
(2.5)^{*}(2.8)^{*} & (2.1)^{*} & (3.3)^{*} & (11.9)^{*} & (1.0) & (2.2)^{*}
\end{array} \\
& +0.6 D 3-4.8 D 4-1.1 D 5-0.9 D 6-0.26 D 7+0.04 D 8-0.64 D 9+1.0 D 10 \\
& (1.1) \quad(6.4)^{*} \quad(1.98)^{*}(1.54) \quad(0.5) \quad(0.07) \quad(1.0) \quad(1.9)^{*}
\end{aligned}
$$

Adjusted $R^{2}=0.17 \quad F=17 \quad N=1132$

2. $P R=-1.4-0.015(P E)+0.00014(P E) 2+5.1 \mathrm{HI}-3.1 A D S-0.48 \mathrm{D} 1-0.9 \mathrm{D} 2$

$$
\begin{aligned}
& (2.1)^{*}(1.61)^{* *} \quad(1.3) \quad(3.2)^{*} \quad(12.6)^{*} \quad(0.88) \quad(1.72)^{* *} \\
& +0.69 D 3-4.4 D 4-0.71 D 5-0.50 D 6-0.10 D 7+0.32 D 8-0.65 D 9+1.2 D 10 \\
& \begin{array}{lllllll}
(1.3) & \left.(5.9)^{*} \quad(1.2) \quad(0.88) \quad(0.19) \quad(0.6) \quad(1.0) \quad(2.1)^{*}\right)
\end{array}
\end{aligned}
$$

Adjusted $R^{2}=0.16 F=16 \quad N=1132$

3. $P R=-1.2-0.10 P B E+5.1 H I-3.1 A D S-0.5 D 1-1.0 D 2+0.5 D 3-4.4 D 4$

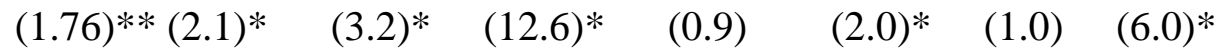

$$
\begin{aligned}
& -0.85 D 5-0.62 D 6-0.24 D 7+0.12 D 8-0.71 D 9+1.0 D 10
\end{aligned}
$$

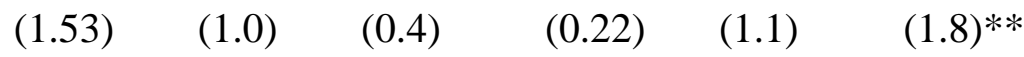

Adjusted $R^{2}=0.16 F=17 \quad N=1132$

Figures in the brackets are $t$-values. * Significant at 0.01 , ** significant 0.05 levels

The above results show high degree of statistical significance and give support for the main hypotheses of the paper. The results of equation 1 show that foreign equity level 
of firms $(F E)$ explains profitability positively and significantly which provides strong support to the argument that FII are able to invest in monitoring the managers of firms and thereby reduce agency costs. However the relationship is not monotonic. The statistically significant positive sign of the estimated coefficient of $F E$ and the negative sign of its squared term imply, profitability of firms increases at a decreasing rate as the percentage of foreign equity level increases. ${ }^{5}$ This provides evidence to the argument that there are agency costs of increasing the share large outside investors beyond a point because of incentives for redistribution of funds and low powered incentives of managers and employees as discussed in the previous section. Apart from this in the case of foreign equity (capital), the costs of risks associated with instability in macro economic variables such as interest and exchange rates are high. Small changes in these variables may cause in foreign capital to move in or out with high frequency which has costs to firms' efficiency. The other two explanatory variables (HI and $A D S)$, as mentioned before, are introduced to control for the market structure effects on profitability of firms. The statistically significant and positive sign of the estimated coefficient of the market concentration variable implies that firms in those industries with higher degree of market concentration tend to show high profits which is a straight forward explanation from the industrial organization literature. However, the statistically significant and negative sign of the coefficient of firm level advertising intensity variable is rather counter intuitive. A plausible explanation could be that firms increase advertising to reduce demand elasticity for their products rather than to increase profits. But this issue is beyond the scope and

5 . The relationship becomes negative at a large percentage level of 45.5 . 
focus of this paper as the purpose of these variables is purely to control for other explanatory variables.

The results of equation 2 provide support to the argument regarding the public financial institutions. The statistically significant negative sign of the estimated coefficient of the variable of public financial institutions $(P E)$ imply that higher the share of public sector financial institutions' investment in a firm lower is the profitability. This provides support to the argument in the previous section that the agents of firms who are able to capture the public financial institutions tend to cause high agency costs through high degree of moral hazard. This in turn reduces efficiency of firms and show low profitability. The results of equation 3 provide support to the hypothesis 3 listed in the previous section: higher is the share of a large number of small investors (the public) lower is the efficiency and profitability of firms. The theoretical explanation is given in the previous section in terms of high agency costs owing to lower ability of small investors in monitoring the managers. This agency costs would be quite significant in Indian economy because the institutional mechanisms protecting small investors are highly inefficient (Goswami, 2001).

To recapitulate, there can be simultaneity in the relationship between profitability and equity level of foreign financial institutions. When FIIs enter the Indian market they search for profitable (efficient) firms to make their investment. Once they make investment they monitor the mangers to ensure efficient operation of firms. This is tested in the following by using technical efficiency of firms $(T E)$ as an instrumental variable for profitability by regressing foreign equity variable against $T E$. First the relationship between profitability and $T E$ is established by regressing $P R$ variable against $T E$. 
4.a. $P R=-2.0+1.0 T E+5.0 H I-3.1 A D S$

$$
(2.7)^{*}(1.81)^{* *}(3.2)^{*}(12.3)^{*}
$$

Adjusted $R^{2}=0.16 \quad F=17 \quad N=1132$

4.b. $F E=16.8+17.2 T E$

$$
(3.9)^{*}(3.5)^{*}
$$

Adjusted $R^{2}=10 \quad F=11 \quad N=1132$

Figures in brackets are $t$-values. *Significant at $0.01 ; * *$ significant at 0.05 levels

In the above estimations, most of the estimated coefficients of industry dummy variables are statistically significant but they are not presented to save on the space. The results of 4.a. show statistically significant positive association between profitability and technical efficiency in production. This justifies using $T E$ as an instrumental variable in the following equation. Secondly, the result confirms the theoretical consistency of the operation of the relation between profits and managerial incentives (the agency costs) through the production efficiency. The results of equation $4 . b$ show statistically significant positive association between technical efficiency of firms and profitability. The results of equations $4 . a$ and $4 . b$, put together, provide evidence to the simueltaneity in the relationship between profitability and equity of foreign financial institutions.

As argued in the previous section, one of the agency costs is empire-building strategies of managers of firm when they have excessive control rights and there is poor monitoring and discipline by the investors. The empire building can be through horizontal and vertical diversification. In this paper, we examine the relationship between 
vertical integration and equity pattern and not horizontal diversification, as we do not have the data on firm level horizontal diversification. As shown by transaction costs economics (Williamson, 1985), one of the reasons for vertical integration by firms is for efficiency reasons of minimizing market transaction costs associated with imperfect information and incomplete contracts. Market transactions costs tend to higher in developing economies such as India where market institutions are inefficient which induce firms to pursue vertical integration (Patibandla, 1998, 1997). Nevertheless, a part of the reason for vertical integration could be for empire building strategies of diversified (family run) businesses. In order test for this, in the following the econometric relation between vertical integration and equity pattern and also between profitability (and TE) and vertical integration is tested.

5. $V E=18-0.00005 F E-0.1 D 1+0.4 D 2+0.03 D 4+0.43 D 5-0.08 D 6-0.018 D 7$

$$
\begin{aligned}
& (18.7) *(1.24) \quad(2.0)^{*} \quad(16.3)^{*}(0.6) \quad(9.7)^{*} \quad(1.63)^{* *}(0.4) \\
& +0.39 D 8-0.017 D 9+0.53 D 10 \\
& (8.7)^{*} \quad(0.34) \quad(17.2)^{*}
\end{aligned}
$$

Adjusted $R^{2}=0.38 \quad F=69 \quad N=1132$

6. $V E=0.8+0.0012 P E-0.56 D 1-0.5 D 3-0.45 D 4-0.05 D 5-0.5 D 6-0.5 D 7$

$$
\begin{aligned}
& (41)^{*}(2.56)^{*} \quad(11)^{*} \quad(16)^{*}(9.1)^{*}(1.1) \quad(11)^{*}(11)^{*} \\
& -0.08 D 8-0.5 D 9+0.05 D 10 \\
& (2.0)^{*} \quad(9.8)^{*} \quad(1.73)^{* *}
\end{aligned}
$$

Adjusted $R^{2}=0.38 F=69 N=1132$

Figures in brackets are t-values. *Significant at $0.01 ; * *$ significant at 0.05 levels. 
The results of equation 5 show a negative association between vertical integration and foreign equity variables but the estimated coefficient is not statistically significant. The results in equation 6 show a statistically significant positive association between vertical integration and public financial institutional investment. This provides support to the argument that the managers of firms who are able to capture the public financial institutions, characterized by high moral hazard, tend to diversify in order to pursue empire-building strategies. In the following the efficiency factors of vertical integration are tested by regressing profitability and technical efficiency against vertical integration.

7.a. $P R=-1.9-0.6 V E+5.0 H I-3.1 A D S$

$$
(2.1)^{* *}(2.5)^{*} \quad(3.0)^{*} \quad(12.6)^{*}
$$

Adjusted $R^{2}=0.16 \quad F=18 \quad N=1132$

7.b. $\mathrm{TE}=0.43-0.02 \mathrm{VE}$

$$
(32)^{*}(1.9)^{*}
$$

Adjusted $R^{2}=0.52 F=123 N=1132$

Figures in brackets are t-values. *Significant at $0.01 ; * *$ significant at 0.05 levels.

For the above results, most of the estimated coefficients of industry dummy variables are statistically significant but are not presented to save on space. The above results show that there is statistically significant negative association between profitability and vertical integration (equation 7a) and between technical efficiency and vertical integration. This implies vertical integration contributes to lower production efficiency and profits of firms. By putting the results of the equation 6 and 7 together, one could say firms that are able to capture the public financial institutions follow nonproductive empire building diversification strategies. 


\section{Conclusion}

The literature in corporate governance show that large outside investors are able to protect their interests better than a large number of dispersed small investors by investing in information, monitoring and disciplining the agents (managers) of corporations. However there are different types of large investors in an economy with varying degrees of moral hazard and agency costs. A large investor, who is protected by governments with taxpayers' money, tends to have higher degree of moral hazard than privately owned large investors. Secondly, managers of firms through collusion can capture the agents of these large investors, which in turn results in diversion of accumulated capital for nonproductive personal goals of the agents.

In the recent years, several developing economies have opened up their financial and equity markets to foreign institutional investors. These institutional investors not only bring efficient institutional practices of corporate governance from developed economies but also are able invest in information to monitor and discipline the managers of firms. This in turn should improve the corporate governance in developing economies by increasing transparency and thereby facilitating convergence in the basic tenets of institutional conditions.

This paper has empirically verified the above issues on the basis of firm level panel data for 11 Indian industries. The results show that higher the share of government financial institutions in the investment lower is the profitability (efficiency) of firms and higher is the share of foreign equity higher is the profitability of firms. However the relation between profitability and foreign equity is non-monotonic: increasing at a decreasing rate. This is explained on the basis of possible agency costs of large share of 
large investors. Apart from this, foreign equity also brings in some element of risks to firms in terms capital flowing in and out of the market depending on the macro economic variables such as exchange and interest rates. The econometric results also show that higher the share of small (public) investors' equity lower is the profitability of firms. This is especially dominant in countries such as India where there are very poor institutional mechanisms of protecting small investors. The misuse of savings of small investors (and taxpayers) operates both in the primary equity markets and also through the public sector financial institutions. When the government owned financial institutions play a major role in channeling public savings into investment under high degree of moral hazard of the agents at different levels, the accumulated capital is underutilized. This in turn causes low economic growth. In order to improve utilization of accumulated capital, it is necessary to reduce the role of public sector financial institutions and build effective regulatory mechanism in the Indian economy. The increasing role of foreign institutional investors would improve the institutions of corporate governance by generating demand for higher degree of transparency. 


\section{Appendix: Measurement of Firm Level Technical Efficiency}

Technical efficiency is defined in terms of magnitude of output realized for any given level of inputs employed. The production function frontier approach of Farrel (1957) is quite effective in measuring micro firm level relative productivity within an industry. The production relation can be expressed as:

$Y=(X: a)+u$, where $Y$ is a vector of input observations and $X$ is a matrix of input observations, $a$ represents the parameters and $u$ represents one-sided error. Frontier estimations take $\mathrm{u}$ to have negative expectation, indicating the presence of (technical) efficiency. In the present case, $u$ is taken to consist of two parts- a normally distributed error term that represents statistical noise and a truncated error term that represents technical inefficiency. Stochastic frontier functions isolate differences in efficiency and random differences among firms by dividing the error term into a deterministic component and a random one. Panel data estimations help in avoiding some strong assumptions. Under the fixed effects approach, there is no need to assume a probability distribution for the inefficiency index and it has the advantage of dispersing with the assumption that firm level inefficiencies are uncorrelated with input levels. The random approach, on the other hand, requires to assume that firm level inefficiencies and input levels are independent but unlike the fixed effects approach, it can accommodate time-invariate variables such as industry or firm dummies. The inefficiency component can be modeled as a function of a number of firm specific factors. Battese and Coelli, 1992 show the simultaneous estimation of both the production function and the inefficiency term. We have taken a two input production with value-added as a function of rental value of capital and salaries and wages as labor input. The values normalized by the appropriate price indices of producer and consumer prices. Both the Translog and the Cobb-Douglas production functional forms are used depending on their fit to the different industries. 


\section{References}

Battese, G., and Coelli, T, 1992, `Frontier Production Functions, Technical Efficiency and Panel Data: With Application to Paddy Farmers in India,' Journal of Productivity Analysis, 3:1/2, 153-169.

Business Today., 1999, 'Fathers, Sons and CEOS', Cover Story, June.

Bhagwati, J., 1993, India in transition: Freeing the economy, Oxford, Oxford University Press.

Beck, T., Levine, R., Loayza, N., 2000, Finance and the sources of growth. Journal of Financial Economics 58, 261-300.

Black, B.S., 1992, Agents watching agents: the promise for institutional investor voice, UCLA Law Review 39, 811-895

Bolton, P. and D.S. Scharfstein, 1998. Corporate finance, the theory of the firm, and organization, Journal of Economic Perspectives 12, 95-114.

Cheng, H., 1986, Analysis of Panel Data, Cambridge, Cambridge University Press.

Cremer, J., 1995, Arms length relationships, Quarterly Journal of Economics, CX, 27596.

Farrell, M, 1957., The measurement of production efficiency, Journal of Royal Statistical Society, 120(3), 253-281.

Goswami, O, 2001, The tide rises, gradually: corporate governance in India, OECD Development Centre.

Henry, P., 2000, Do stock market liberalization cause investment boom? Journal of Financial Economics 58, 301-334.

Jensen, M.C. and W. Meckling, 1976, Theory of the firm: managerial behavior, agency costs, and ownership structure, Journal of Financial Economics 3, 305-360.

Khanna, T and K. Palepu 1999 Emerging Market Business Groups, Foreign Investors and Corporate Governance, NBER Working Paper No. W6955

Moerlan, P.W., 1995. Alternative disciplinary mechanisms in different corporate systems, Journal of Economic Behavior and Organization 26, 17-34.

La Porta, R., F.Lopez-de-Silanes, A.Shleifer, and R.Vishny, 1998, Legal Determinants of External Finance, Journal of Finance, 52, 1131-50. 
Patibandla. M, 2001., 'Policy reforms and evolution of market structure in an emerging economy', forthcoming in the Journal of Development Studies.

Patibandla, M., 1998, 'Structure, Organizational Behavior and Technical efficiency', Journal of Economic Behavior and Organization, 34 (3): 419-434.

Patibandla, M, 1997, Economic reforms and institutions, Economic and Political Weekly, May17-24, 1083-1090.

Piramal, G, 1996, Business Maharajas, New Delhi: Penguin Books India.

Schmidt, K., 1990, The costs and benefits of privitization, University of Bonn Discussion Paper, A-287.

Shleifer, A and R. Vishny 1986, 'Large Shareholders and Corporate Control', Journal of Political Economy, 96, 461-88.

Shleifer, A and R. Vishny 1997, ‘A Survey of Corporate Governance' Journal of Finance, 52, 737-83.

Stein, J.C, 2001, Agency, information and corporate investment, NBER working paper 8342.

Stultz, R.,1999, International portfolio flows and securities markets, Working paper 99-3, Fisher College of Business, The Ohio State University, Columbus, OH.

Sutton, J, 1992, Sunk Costs and Market Structure: Price Competition, Advertising and the Evolution of Concentration, Cambridge: The MIT Press.

Thomsen, S and T. Pedersen 2000. Ownership structure and economic performance in the largest European companies, Strategic Management Journal 21, 689-705.

Williamson, O.E , 1985, The Economic Institutions of Capitalism, Free Press, New York.

Woidtke, T. 2001, Agents watching agents?: evidence from pension fund ownership and firm value, Mays College of Business, Texas A\&M university. 
Table 1. Foreign Investment Inflows in India US \$ million

\begin{tabular}{|l|l|l|l|l|l|l|l|l|}
\hline & $1992-93$ & $1993-94$ & $1994-95$ & $1995-96$ & $1996-97$ & $1997-98$ & $1998-99$ & $1999-0$ \\
\hline $\begin{array}{l}\text { A.Direct } \\
\text { investment }\end{array}$ & 315 & 586 & 1314 & 2144 & 2821 & 3557 & 2462 \\
\hline $\begin{array}{l}\text { B.Portfolio } \\
\text { investment }\end{array}$ & 244 & 3567 & 3824 & 2748 & 3312 & 1828 & -61 \\
\hline $\begin{array}{l}\text { a.GDRs/ } \\
\text { ADRs }\end{array}$ & 240 & 1520 & 2082 & 683 & 1366 & 645 & 3026 \\
\hline FIIs* & 1 & 1665 & 1503 & 2009 & 1926 & 979 & 768 \\
\hline Total(A+B) & 559 & 4153 & 5138 & 4892 & 6133 & 5385 & -390 \\
\hline
\end{tabular}

* Foreign Institutional Investors

Source: Reserve Bank of India

Table2: The Sample

\begin{tabular}{|c|c|c|c|c|c|c|}
\hline Industry & $\begin{array}{l}\text { Dum } \\
\text { my }\end{array}$ & $\begin{array}{l}\text { \# of } \\
\text { firms }\end{array}$ & $\begin{array}{l}\text { \# } \\
\text { Observatio } \\
\text { ns }\end{array}$ & $\begin{array}{l}\% \text { Average } \\
\text { Foreign Equity }\end{array}$ & $\begin{array}{l}\text { \%Average } \\
\text { Public Financial } \\
\text { Institutions }\end{array}$ & $\begin{array}{l}\% \text { Average } \\
\text { Equity Held } \\
\text { by The Public }\end{array}$ \\
\hline Airconditioners & D1 & 5 & 54 & 18.8 & 6.5 & 24.3 \\
\hline $\begin{array}{l}\text { Auto } \\
\text { Ancillaries }\end{array}$ & D2 & 24 & 264 & 21.2 & 17.2 & 22.0 \\
\hline $\begin{array}{l}\text { Communication } \\
\text { Equipment }\end{array}$ & D3 & 22 & 227 & 14.7 & 36.5 & 19.0 \\
\hline $\begin{array}{l}\text { Electronic } \\
\text { Process } \\
\text { Control }\end{array}$ & D4 & 5 & 52 & 30.7 & 13.0 & 32.36 \\
\hline $\begin{array}{l}\text { Light } \\
\text { Commercial } \\
\text { Vehicles }\end{array}$ & D5 & 6 & 72 & 30.4 & 14.5 & 20.0 \\
\hline Motor Cycles & D6 & 4 & 48 & 35.2 & 6.5 & 14.7 \\
\hline $\begin{array}{l}\text { Motors and } \\
\text { Generators }\end{array}$ & D7 & 6 & 66 & 29.3 & 15.0 & 21.0 \\
\hline Passenger Cars & D8 & 10 & 68 & 44.2 & 14.0 & 13.2 \\
\hline Refrigerators & D9 & 4 & 47 & 21.2 & 18.0 & 31.0 \\
\hline $\begin{array}{l}\text { Tyres and } \\
\text { Tubes }\end{array}$ & D10 & 19 & 197 & 12.8 & 26.0 & 26.4 \\
\hline $\begin{array}{l}\text { Washing } \\
\text { Machines }\end{array}$ & & 5 & 37 & 27.8 & 13.0 & 29.0 \\
\hline
\end{tabular}

